\title{
EMILIN1 wt Allele
}

National Cancer Institute

\section{Source}

National Cancer Institute. EMILIN1 wt Allele. NCI Thesaurus. Code C52483.

Human EMILIN1 wild-type allele is located within 2p23.3 and is approximately $8 \mathrm{~kb}$ in length. This allele, which encodes EMILIN-1 protein, plays a role in the regulation of both blood vessel structure and transforming growth factor beta signaling. 